\title{
De hija a madre: la negociación de la identidad de género en una historia de migración desde Perú hacia Europa
}

\author{
Leslie Nancy Hernández Nova*
}

\section{El origen de la memoria migratoria colectiva}

Ciertas cosas no se saben hasta que no se escuchan las "malas lenguas". Esto mismo sucede con la visión de la "gente", lo que solloza, lo que narra cuando se pone en juego aunque también en entredicho. El tener que vivir - por ejemplo - una crisis económica implica dar una respuesta, una interpretación. La importancia que puede notarse con el estudio de las migraciones actuales a través de la historia oral no es el estudio de los fenómenos en sí, sino más bien de la subjetividad entremezclada a ellos; los eventos explicados a partir de sus actores, pues como recuerda Luisa Passerini "La historia oral, no obstante su nombre sugiera parcialidad, hace surgir la esperanza de una respuesta diferente" (Passerini, 1978, p. VIII).

Estudios actuales que recogen memorias femeninas de la diáspora peruana hacia Europa, principalmente hacia Italia (Hernández, 2006; Tamagno, 2005), muestran opiniones acerca de una crisis condivisible, pues éstas describen como la motivación principal de la decisión de emigrar la crisis económica de los años noventa, evento impreso en la memoria colectiva, comúnmente recordado por la sociedad peruana como el 'fujishoc'1: "Sobre todo en la última década [en los años 90’s] con el

\footnotetext{
* Investigadora y docente del Departamento de Historia de la Università degli Studi di Torino, Italia.

1 En realidad se trata del Programa de Ajuste Estructural impulsado por el presidente Alberto Fujimori en 1990.
} 
'fujishoc', el hecho de que el Perú esté [estaba] en una situación tremenda, tantísima gente ha decidido emigrar sobre todo por motivo económico, por una voluntad propria de superarse". ${ }^{2}$

Es así como lo describe Tamagno: "[...] la crisis de la década de los años 90's fue una de las peores que haya atravesado este país, donde los shocks económicos, aplicados por el Estado, casi arrastraron con la empobrecida clase media. En este periodo, apareció la extrema pobreza (como una nueva categoría), las diferencias sociales se ahondaron y las expectativas de vida se limitaron" (Tamagno, 2005, p. 334). Como diría Elena Poniatowska cuando recuerda la vida que se vive en México, Perú, Brasil, Argentina, Guatemala, El Salvador, Uruguay, Ecuador, etc.: "Los pobres son simplemente los otros" (Poniatowska, 2007, p. 97).

Existen otros aspectos que encaraman la decisión de emigrar en los movimientos actuales: la necesidad de vivir mejor desde el punto de vista de las condiciones de la mujer, casi siempre permeadas de carencias amplias y profundas, en el sentido más práctico y más subjetivo: la precariedad vivida en la esfera familiar, la desigualdad de género, la búsqueda de conocimiento e incluso la necesidad de un cambio drástico en la vida. En algunos casos, la selección migratoria entreteje por sí misma discursos con proyectos emancipatorios que hablan mucho del empeño de las mujeres para levantarse y mostrar al sexo opuesto sus capacidades. En muchos casos, la migración sirve para escapar de situaciones difíciles y de maltratos (físicos y psicológicos) vividos en el ambiente familiar. También en otros, es la distancia que procura la experiencia migratoria que da las condiciones para la negociación, para nuevas dinámicas en las relaciones de género.

Por otro lado, en el imaginario colectivo peruano encontramos imágenes de zonas de emigración que se difunden rápidamente y determinan los flujos a partir de preferencias: "Yo, por la información que tenía, Estados Unidos era la opción para mi esposo, porque él tenía su hermana allá. Pero la información que nos llegaba era que por la situación económica [Europa] estaba mejor que Estados Unidos. Inclusive en Perú, la gente en Perú dice: "Ya no quiero ir a Estados Unidos, mejor me voy a

2 De mi entrevista a Magdalena (pseudónimo elegido por la testigo), realizada en lengua española en Turín el 13 de enero del 2005-Archivo areia. 
Europa"(ríe)". ${ }^{3}$ La imagen de la dirección que emprende el éxodo peruano femenino se define y expande con una visión común: "irse para Europa". La declaración "me voy para Europa" muestra nítidamente que al territorio europeo se le percibe como un bloque único e indivisible. Según algunas narraciones de mujeres, generalmente primero se llega a España y de allí se dirigen hacia otros paises de la Unión Europea: "Más que nada van a Europa, a España y de España ya se transfieren a otros países. No eres tú la que escoge el país, son los contactos que logras conocer por personas conocidas que ya fueron [que] te dicen como es". ${ }^{4}$ Sus actores son prevalentemente mujeres ${ }^{5}$ solas que viajan sin su familia y se han especializado en el trabajo del cuidado a ancianos, enfermeras y trabajos domésticos.

Una serie de peculiaridades importantes de la diáspora peruana derivan de la acumulación de varias experiencias de migración. Para la mayor parte de sus actores se trata de experiencias de migración interna emprendidas junto con sus familias en varios momentos de la vida. Se trata del traslado a otras ciudades, principalmente desde poblados de la sierra hacia la costa limeña durante el periodo que va del 1940 al 19806 . Para una menor parte la experiencia migratoria precedente que se presenta es al interior de la misma región Andina y en otros hacia Argentina.

Otro aspecto interesante de la migración internacional peruana es el nexo entre el pasado inmediato de la violencia política que vivió el país a partir de los años 80s cuando surge el "Partido Comunista Peruano Sendero Luminoso" con el presente "transnacional" migratorio que atraviesa cotidianamente el país. De mi trabajo de campo realizado desde el 2001 en Turín (también posteriormente en toda la región de Piemonte) y sucesivamente en Perú, no he visto emerger casos de esta composición migratoria, es decir, de migración forzada como estrategia de sobrevivencia a

3 De mi entrevista a Azucena (pseudónimo), realizada en lengua española en Biella el 15 de noviembre del 2008-Fondazione Sella di Biella.

4 De mi entrevista a Natalia (pseudónimo), realizada en lengua española en Turín el 5 de septiembre del 2005-Archivo areia.

5 En Italia, según datos del ISTAT, la población peruana que residía regularmente hasta el 31 de diciembre del 2008 era de 77,629 de los cuales 30,883 eran hombres y 46,746 mujeres.

6 También el muestreo realizado por Carla Tamagno en el 2005 de la comunidad peruana en Milán arroja datos similares pues en un $67 \%$ de sus entrevistados proceden de poblados de la Sierra. 
la represión, a la exclusión y a la conservación de la vida misma. Sin embargo, puedo apuntar un ejemplo que resalta a partir de algunos datos estadísticos sobre los ciudadanos peruanos residentes en Turín por Municipio de nacimiento, que demuestran que a esta ciudad habían emigrado, hasta el 31 de diciembre del 2006, 110 personas de un total de 6018 residentes regulares (41 hombres y 69 mujeres) que provenían específicamente de la zona de Ayacucho.

Algunos investigadores peruanos (Tamagno 2005; Altamirano, 1992; Golte, 1990) indican a la migración interna ${ }^{7}$ como la premisa de la cual resulta la migración hacia el extranjero de los y las peruanas. En efecto la migración interna - motivada por diferentes causas que vivieron muchas familias - crea las condiciones de una ponderosa memoria colectiva migratoria que más tarde se transmite como conocimiento (traducible asimismo en una actitud social) hacia las nuevas generaciones; se explicita como medio-estrategia para dar solución a los problemas de la vida cotidiana, empero también para curar carencias en el ámbito más íntimo y privado intersubjetivo, identitario y de género (disparidad y desigualdad en las relaciones de género).

Tal como José María Arguedas describía el mecanismo de puente construído por los primeros migrantes de Lima, "Los ya "residentes" en Lima les sirven de "cabeza de puente" para el gran salto" (Arguedas, 1977, p. 5), lo mismo se repitió hacia el extranjero.

Para poder visualizar esta trayectoria común presente en la diáspora peruana, quizás sea menester valernos de un testimonio en donde emergen de manera nítida y breve los diferentes espacios de este tránsito interno y externo a Perú. Se trata de un mapa migratorio oral que ví emerger al transcribir una de mis entrevistas realizadas en Turín en el 2005; un mapa migratorio verbal y discursivo a través de una aparente sucesión de palabras:

\footnotetext{
7 Para comprender la magnitud de la migración interna es necesario apuntar que en tan sólo 40 años la composición de la población total, que inicialmente en el 1940 era en un 65\% prevalentemente rural, para el 1981 este mismo porcentaje correspondía a la población urbana (Cfr. Altamirano, 1992, p. 63). La Reforma Agraria del 1969, no contrarresta el abando evidente de la tierra; se calcula que "entre el 1940 y 1981 la población de Lima aumentó siete veces: de 645.2 mil a 4,608.0 mil habitantes” (Cfr. Golte, 1990, p. 38).
} 
Santa Anita, en Lima. En Lima mismo. De Huancayo, mi pueblo, a Lima [...] Yo llegué clandestina a Italia [pagando] 4 mil dólares en el $1994 .{ }^{8}$

Este mapa se me rindió visible gracias al pasaje de la oralidad a la escritura, cuando el historiador puede organizar los fragmentos del tiempo narrado (Jauss, 2003), proceso largo que inicia desde la entrevista y que no se disuelve durante la transcripción, sino por el contrario más tarde, cuando se pueden observar sus extemidades. Esto concuerda con cuanto escribe Ong a propósito del nexo entre oralidad y escritura, pues "La oralidad y la escritura son ambas necesarias para la evolución de la conciencia" (Ong, 1986, p. 241).

Como se verá en los apartados siguientes, el estudio de las migraciones actuales, a partir de historias individuales y familiares respecto a esta experiencia, permite explorar los diferentes impactos del transnacionalismo en los lugares de partida, de tránsito y de residencia de sus actores; los espacios, los tiempos y las formas que ellos atraviesan, así como la subjetividad que éstos asumen. Las historias de vida son muestra sublime de la continuidad, la discontinuidad y los silencios.

Por otro lado, la similitud que se establece entre sus actores a partir de la experiencia migratoria interna lo convierte en un verdadero comienzo de los recuerdos de la historia de vida y, precisamente por esto, en la memoria colectiva emerge una cierta cultura de la movilidad. Y no únicamente, pues también se expresa con la forma de la experiencia más antigüa en la vida privada y pública. Aún puedo añadir el fragmento de una narración autobiográfica para interpretar nuestros mapas de la migración peruana: "Hablar en este momento de mi historia es de seguro contarles la historia de tantas personas inmigrantes, es sin duda tocar tantos lugares comunes, tocar tantos puntos que son un "común denominador" para todos aquellos que viven como "huéspedes", que viven en un lugar en donde no nacieron" $"$

8 De mi entrevista a Karina (pseudónimo elegido por la testigo), realizada en lengua española, Turín, septiembre del 2005.

9 La narración lleva el título "Hai scoperto chi sei?” y fue escrita por Francisca Abregú López, actualmente residente en Italia. Forma parte de un volúmen que recoge muy variados testimonios de experiencias migratorias. La compilación es de Daniela Finocchi en colaboración con el Centro Studi Documentazione Pensiero Femminile titulado Lingua madre duemilasei.Racconti di donne straniere in Italia. Turín: Edizioni Seb 27, 2006, pp. 15-18, 15. 
Según algunos testimonios de mujeres que se destacan por su labor en la gestión o participación activa en el asociacionismo migrante, residentes en Italia, están convencidas del hecho que el modelo comportamental migratorio que nace con la migración interna se repite en Italia:

Nosotros acá [en Turín]. Digo que es el mismo modelo de migración porque los modelos de inmigración nosotros los estamos repitiendo. En Perú cuando se ha hablado de inmigración interna, las primeras personas que vinieron a Lima fueron las mujeres. [...] Hemos venido primero las mujeres, por tantas razones, porque los trabajos son más fáciles, porque la mayor parte de las personas que venían casadas escapaban porque el marido les pegaba y entonces, entre comillas [aparentemente], psicológicamente huían de los problemas familiares. [Sin embrago, luego] llegaban acá y era peor (se ríe). Pero ha sido el mismo modelo, se han encerrado fissas ${ }^{10}$ y los sábados y los domingos ¿dónde los encontramos acá? En los parques. ${ }^{11}$

Si quisiera simplificar - ya no digamos - la narración sino toda la información que hemos decidido yuxtaponer, vemos que la memoria establece una fuerte identificación con la historia. Como señala Paul Ricoeur: "Lo más difícil no es narrar de otra forma o dejarse narrar por los otros, sino narrar de otra forma los eventos fundadores de nuestra identidad colectiva, principalmente nacional [...] Es en este nivel de la identidad colectiva que se tendría que poder elevar la noción de sí mismo como si fuera otro" (Ricoeur, 2004, p. 91-92).

\section{Rapidez: ritmo que el evento migratorio imprime a la memoria}

Hay un espejismo humano que genera la razón: el tiempo. Los tiempos cotidianos son materia de la máquina de la vida moderna que se reproduce sin cesar sobre todo a través de los silencios y las pausas. ¿Cómo pode-

10 fissas (mezcla lingüística): fija, de planta, cama adentro (esp.), fissa (ita.).

11 De mi entrevista a Carmen (pseudónimo), mujer integrante del asociacionismo migrante, realizada en lengua española en Turín el 3 de febrero del 2005-Archivo AREIA. 
mos relacionar a la imagen que posee el tiempo con el fenómeno de la migración?

Una certeza - casi inevitable - es que la percepción del tiempo histórico cambia con la migración. Aunque se trata de una desapariencia, muchas de las causas por las cuales durante las narraciones de mis testigos demostraron un - aparentemente - discurso continuo y discontinuo era debido a la voz articulada del pasado con el presente. Como señala Luisa Passerini "la historia oral comparte esta duplicidad [...]. Lo nuevo que introduce en la historia son discursos, que dan cuenta de una realidad que puede ser múltiple y debe ser decifrada" (Passerini, 1978, p. IX).

En el escenario de la migración, se exige a los sujetos migratorios una especie de consciencia que no pertenence necesariamente a la participación de cualquier sujeto social. Este presupuesto podría asemejarse a la descripción que hacían Carl Jung acerca de las peculiaridades que posee el "hombre moderno" pues como él mismo señala: "[...] no basta vivir en la actualidad para ser modernos porque en este caso todos lo serían, sino que solamente lo es aquél que es verdaderamente consciente del presente en el que vive.” (Jung, 1994, pp. 276-277). Según esta idea de Jung, la consciencia se vuelve una actitud fundamental para interactuar con el mundo y se manifiesta cuando el individuo realiza reelaboraciones de sí mismo "relacionándose" con el pasado.

En la misma dirección, Luisa Passerini describe la consciencia como actitud participativa del sujeto, identificable gracias a la narración autobiográfica que el testigo realiza sobre acontecimientos pasados, en donde la narración se vuelve una intervención consciente desde el pasado hacia el presente y el futuro: "por irrevocable que éste sea, una intervención consciente puede salvar el sentido de eso que sucedió" (Passerini, 1978, p. XXVIII). La relación que describe Passerini del individuo con el pasado es aún mayormente compleja, pues no sólo describe la actitud consciente del individuo respecto al contexto en el que vive de la cual habla Jung, sino que también considera a las formas que el pasado - debido a una intervención cosicente en las memorias de este - puede manifestar en el presente, en la vida individual y en aquella colectiva. Esto significa asimismo, que las experiencias de vida toman forma de colectividad gracias a este ejercicio reflexivo de consciencia individual acerca del pasado, que, como expresa esta fórmula descrita por Passerini, resulta difícilmente destruible y potencialmente transmisible. 
Quien emigra, percibe la rapidez con la cual se vive, la sencillez con la cual se percibe el mundo: la saturación, la hipertrofia de la memoria. Dicho de otra forma, antes de emigrar, la persona se convence de sus incapacidades, de su poca participación en la reelaboración de su mundo. Su deseo, además de conocerlo, es de fusionarse con éste; por eso la elección de emigrar podemos considerarla semejante al concepto de "hombre moderno"; uno de los hechos decisivos de la modernidad es la culpa - tal como dice Carl Gustav Jung - porque está ligada a la falta de conocimiento.

La migración es un fenómeno que expresa la falta de novedad e innovación, ya sea en la historia como en ámbito del conocimiento, pero también el deseo de fusión. Y más: hibridización. La siguiente definición de Anne Marie Fortier describe aspectos y tensiones del atravesamiento del sujeto migratorio, poniendo en juego los diversos espacios y actores:

La emigración representa la base de un terreno cultural nuevo que se sitúa entre localismo y transnacionalismo; un tercer espacio diaspórico [...] que constituye tensiones entretejidas, que en su conjunto traen consigo nuevos sitios para las pertenencias acerca de los problemas de percepción del espacio de la nación, del 'hogar' y de la 'comunidad': tensiones entre aquí y allá, mayorías y minorías, continuidad y cambio (Fortier, 2000, p. 157).

Con la migración internacional presenciamos un "tiempo inverso". El pasado es el futuro y el futuro es el pasado. Esta fórmula se refiere a la retrospección de la historia, así como a los espacios originales recreados por ella misma. Dicho de otra forma, el futuro es la creatividad del pasado. También Paul Ricoeur escribe algo parecido describiéndolo como la contrapartida del tiempo o "movimiento inverso": "La última cuestión es si, a pesar del enfoque retrospectivo del conocimiento histórico, en el corazón de los conocimientos de los hombres de antaño, no sea posible identificar algún efecto secundario de orientación hacia el futuro" (Ricoeur, 2004, p. 36).

Más que una reflexión racional, parece un juego de la física. Sin embargo, la rapidez con la cual la tecnología explica los fenómenos deja casi sin habla al futuro en donde la visión y las aseveraciones acerca de éste se vuelven - en brevísimo tiempo - en reminiscencia. Es por esto que 
el tiempo por venir ya no puede verse sino como pasado. En nuestra época, no sólo el proceso de la innovación tecnológica ha ido intensificando el ritmo de las metamorfosis en las sociedades, lo es también y en igual manera la migración, pues esta última ha acelerado la proyección humana en una vocación mundial: movimiento e innovación.

Aún añadiría un fragmento de la reflexión que nos mostraba Paul Ricoeur sobre el "movimiento inverso": "Quisiera mostrar cómo estas repercusiones de la orientación hacia el futuro sobre el pasado, sean en realidad la contraparte del movimiento inverso, por lo que la representación del pasado influye en la del futuro" (Ricoeur, 2004, p. 36).

La gran característica de este nuestro momento en la historia de las sociedades tiene un rasgo común: la separación. No es la excéntrica multiplicación de consciencias a influir el pensamiento de las sociedades, es más bien la pugna por lograr el diálogo a través de las lenguas de las diferentes culturas lo que se quisiera instaurar. La separación entre nuestras sociedades no se procura por sus ciudadanos, por el contrario. Mi convicción es que la figura del migrante enseña y deja entrever las entrañas de una historia cultural que nos une y que nos separa: "La consciencia de la separación es una nota constante de nuestra historia espiritual. A veces sentimos la separación como una herida y entonces se transforma en escisión interna, consciencia desgarrada que nos invita al examen de nosotros mismos; otras aparacen como un reto, espuela que nos incita a la acción, a salir al encuentro de los otros y del mundo" (Paz, 1994, p. 33).

Ahora bien, si la historia es separación y unión ¿esto significa que es irreversible? Mi convicción es que la historia no es quien tiene la última palabra, la historia es un proceso, es la conección de puentes que, a su vez, manifiestan premisas para luego actuar como metástasis en el amplio tejido social. La historia se vale ante todo de relaciones humanas, es aquí donde verdaderamente se condensan las grandes tensiones de una cultura. Por ello, a través de la oralidad lo público y lo privado, lo interno y lo externo es visible. (Vangelista, 2004)

Un migrante, entonces, no es sólo aquél que decide irse a otro territorio, sino más bién todo aquél que ha desempañado - dentro de sus posibilidades - la mutación del mundo con percepción y razonamientos y que se ha ido creando un mapa esencial que lo legitime como individuo, y que le de un rol y lo reconozca como miembro de una sociedad; empero también como parte de una cultura, de un lenguaje. Y más: de 
una historia. Esta cuestión del origen de sí mismo se reúne con otro factor con el cual tiene que identificarse y reconocerse: el tiempo.

La memoria de Miska se concentra en el evento de la partida de la madre porque representa la ruptura y el olvido. La rapidez de concretización del evento tiene sentido si se tienen en cuenta el nuevo trayecto o bien historia impuesta a la niña. La decisión de emigrar de la madre fue veloz, la inmediatez aparentemente indolora. Sin embargo, la figura del olvido -como veremos- mayormente presente, se encuentra estrechamente relacionada a la memoria interior y a la memoria emocional. Empero existe un lazo aún peor a la figura del olvido, que puede provocar repercusiones emocionales más profundas "que hieren dolorosamente y que a veces son crudeles, la memoria cronológica: la memoria calculadora" (Borgna, 2009, p. 137).

Con este análisis no se quiere llegar a una imagen idealizada del problema del individuo social, de las relaciones de género; ni tampoco sobre la existencia humana, sino más bien ensayar un esbozo a partir de elementos recolectados en el trabajo de campo que explican, en parte, la interacción y los mecanismos que han despertado a la memoria individual de la persona migrante y la colectiva en una instancia mayor: una nueva cultura que nace a partir de la experiencia migratoria en Italia.

\section{El mapa migratorio imaginario}

No es necesaria la vista para la elaboración de un "mapa mental", basta la transmisión del conocimiento para llevarlo a cabo, para separar los elementos geográficos de la abstracción real, para traducir, en los relieves de la figura mental, al tiempo histórico y a la memoria.

Calculando la trayectoria migratoria a partir de la decisión de emigrar, o bien como he querido llamar la acción del irse, se desencadena un conflicto de percepción espacial que consiste primero en la desaparición, luego en el traslado y en la aparición en un nuevo sitio; un proceso que, para quien lo emprende, da como resultante la sucesión de los espacios recorridos. Los espacios cobran coherencia en un lenguaje narrado y oral que puede ser decifrado. La historia oral ofrece "el lenguaje en su totalidad, no sólo el de los hombres ilustres sono de la gente común, no sólo las lenguas cultas, $[\ldots]$, no sólo la expresión explícita sino los códigos des- 
articulados de aquellos que no gozan de voz oficial y que en cambio ésta los costringe a dar el testimonio de su vida" (Passerini, 1978, p. IX).

La relación que se establece entre la persona y la representación de su mapa acerca del mundo está mediada por la información que fluye con la comunicación en general. Los familiares de los migrantes demuestran su visión del tiempo y de la historia a través de una observación participativa del fenómeno, que puede llevarse a cabo de manera activa o pasiva. Federico Boni hace referencia al concepto de Lévi Strauss de bricoleur para referirse a la construcción que se produce a partir de los medios de comunicación como la construcción de la identidad en los home pages, que significa apropiarse de materiales "ya listos" en una especie de "ready mades" cultural (Boni, 2005, p. 145).

Para nosotros, entonces, el valor de la obra mental "cartográfica" de los espacios recorridos reside en la apropiación del conocimiento ya elaborado y transmitido más de una vez en más de un lugar, dentro del real mapa-mundi. Este conocimiento se encuentra en las ciudades, por eso la ruta de la Sierra a la Costa de la migración interna peruana entre los años que van del 1940 al 1981 muestra también la forma de las ciudades de paso hacia el exterior en direcciones muy diversas: "La ciudad moderna no es sólo la vida pública, el espacio público y el privado se confunden en ella. Cada vida y cada biografía, por más individual que parezca, es pública y colectiva; a su vez, la historia es un tejido de pasiones individuales y de accidentes en la que las personas no son menos determinantes que los llamados determinismos sociales" (Paz, 1994, p. 118).

La experiencia de la migración interna de Perú nos sirve para afirmar que la historia es movimiento, continuidad y separación, pues la migración peruana hacia Italia es la acción futura que regresa al pasado. Paul Ricoeur escribe acerca del proceso interpretativo del pasado como un caso de acción retroactiva desde el punto de vista de la aprehensión del pasado en donde "la memoria a la que se regresa desde el futuro oferce el modelo de la consciencia histórica [...] En este sentido la memoria proviene de una abstracción de la dimensión del pasado, abstraída de la dialéctica de las tres dimensiones temporales" (Ricoeur, 2004, p. 93). Lo que señala Ricoeur es que existe una distancia específica y real que puede medirse entre un evento y otro gracias al recuerdo que se tiene de éste.

Quizás sea este mismo mecanismo que se reproduzca en el plano emotivo, si quisiéramos interpretar en estos términos lo que ocurría a 
Miszka cuando pensaba a su madre, pues se anteponía una distancia del todo abstracta que se erguía con el recuerdo del pasado, es decir, la partida de su madre hacia Europa - quien emigra primero a España, a Toledo en el 2002 - con la realidad que se traducía en la impresencia de su madre prolongada en el futuro, pues luego de algunos meses se traslada a las cercanías de Turín.

Si insertáramos esta trayectoria migratoria de la madre en aquellas trayectorias seguidas paso a paso por las comunidades que constituyen la diáspora femenina peruana, encontraríamos que no corresponde a la primera onda migratoria del grupo de los "viejos migrantes" - que como habíamos dicho - se caracterizaba por que muchos de sus sujetos habían vivido previamente una experiencia de migración interna, sino más bién a una onda posterior de "nuevos migrantes" que se caracteriza por basar la partida según las redes - resultado de las primeras "cabezas del puente - que establecieron ciudades intermedias (Tamagno, 2003) como más tarde lo sería Trujillo - además de Lima - que vería pasar el tránsito hacia el extranjero."

Una convicción personal es que con la experiencia migratoria se activen algunas emociones; quizás las más significativas y recurrentes son la muerte simbólica ("muerte chiquita") y el abandono. Se trata de emociones presentes en la esfera personal emotiva que se alargan y acompañan la trayectoria y los traslados de los sujetos migratorios.

La emoción de Miszka respecto la migración es la de abandono que se esclarece durante nuestra entrevista gracias a la colocación geográfica que le ofrece los trazos del mapa del mundo. Pues un fuerte deseo me trasmitió Miszka, colocar la emoción de abandono producida por este evento migratorio en un ambiente geográfico, convertir este hecho en algo tangible; deseo que durante nuestros diálogos se convertiría en un mapa del mundo, en una fotografía del lugar de migración de la madre y en una carta para ella. Cuando termina la entrevista, la pequeña da un significado al hecho tangible y físico de la ausencia de la madre. Lo que resulta, como bien describe Jean Paul Sartre, es una "imagen mental" en la cual es posible dar una justa posición a su emoción. Por otro lado, la decisión migratoria de la madre interpretada como "hecho físico", tal como lo consideraría Sartre, en Miszka se manifiesta un significado personal del cual ya no es posible separar tal emoción. Cito Sartre "una emoción lleva a su significado y eso que es su significado es de hecho la 
totalidad de las relaciones de la realidad humana en el mundo". (Sartre, 1995, p. 122). En este sentido, a la imagen de las ciudades de emigración de la madre se les puede colocar su emoción. Si tuviera que sintetizar su narración en un cuadro general, lo expresaría valiéndome de la siguiente dicotomía: visibilidad-invisibilidad.

Cuando entrevisté a Miszka, lucía verdaderamente con su alma sin rumbo, la imagen ideal de Miszka del mundo cubría un elemento faltante en su vida; la unión de la brecha que la distancia y la lejanía de la relación maternal se había impuesto entre Trujillo y un poblado de la región Piemonte de Italia, del cual ella no conocía ni siquiera el nominativo geográfico exacto. Desde la partida de la madre - que, como dije antes, sucede a finales del 2002 -, la precisión y la exactitud de los hechos de cualquier género carecían de valor $\mathrm{y}$, a menudo también, de memoria, pues todos los recuerdos se perpetuaban en un solo: el nexo entre irse y ser abandonado ocasionado por la migración.

Esto explica por qué las memorias de su infancia -incluso las más remotas - tienen origen en el momento de separación de la madre cuando emigró. Así como también nos aclara por qué la pequeña dejó de ser partícipe de su tiempo y de su mundo, en general de su vida; tal y como si este evento familiar hubieran paralizado prácticamente todas sus experiencias, incluso aquellas construídas gracias a la identitad colectiva fruto de los momentos de diálogo con otros niños y niñas de su edad. Eran tantas sus preocupaciones que no emergían informaciones en relación a las representaciones colectivas de sí misma y de los demás, lo que podríamos llamar "estereotipos nacionales de la infancia". ${ }^{12}$

Debo confesar que ésta sea la entrevista más complicada que hasta ahora yo haya realizado, en donde la lucidez y la subjetividad simplemente se mezclaban. ¿Cómo describir nuestra conversación y encuentro? Estábamos a solas en un aula vacía, cuyas ventanas daban al patio interno de la escuela. La pequeña mecía entre sus ideas las penalidades que le afligían constantemente: separación y abandono en una olla colma de problemas familiares que he decidido, en parte, mantener en silencio. Ella no me escondía nada y yo tampoco.

12 A propósito del tema de la cultura infantil y sus mutamentos socioculturales véase el artículo de Heinz Hengst Modelli d’infanzia nelle trasformazioni socioculturali oggi. Per una sociologia dell'infanzia. Milano: Franco Angeli, 2004, pp. 188-227. 
Con gran admiración pude darme cuenta que entendió mi cometido y objetivo de nuestra charla. Le expliqué el por qué de mi presencia en su escuela, de mi investigación y de la actividad didáctica que me encontraba a desarrollar dando charlas sobre la migración de mujeres peruanas hacia Italia en varias instituciones de educación primaria, media y superior. Mostraba curiosidad y mucho interés sobre todo por saber, por tener mayores y más precisos datos sobre aquel lugar imposible de imaginar sin la ayuda de alguien - en el que su madre vivía actualmente. Los pocos datos que ella tenía coincidían todos con los mios: Italia y la migración de mujeres. Resulta curioso que las respuestas las buscara en mi cuaderno de apuntes. Repetidas veces señaló con su dedo índice mi cuaderno para transmitirme su necesidad de lograr ver algunas respuestas. En realidad Miszka deseaba que en mi cuaderno le mostrara a su madre. Si cuento esto es porque, incluso en la fase de transcripción, me pareció nuevamente encontrar una emoción que no se extinguió. Aún después de tanto tiempo, el recuerdo de nuestra entrevista roza y despliega una parte espiritual en mi crónica del trabajo de campo. Si describo la emoción recabada en esta historia de vida es porque creo en la substancia del simbolismo de la fraternidad vivida en forma de entrevista mencionada por Philippe Joutard quien dice que: “[...] en la medida en la cual un estudio histórico [...] muestra que 'el histórico se refleja completamente en su historia' (Marrou) y, en tal forma, da cuenta de su época y su ambiente, [por ello] me parece equitativo ponerme 'en cuestión' antes de describir la de los otros" (Joutard, 1977, p. 9).

A pesar de todas sus preocupaciones permitió, por alguna razón, que mi persona se intrometiera en lo que le sucedía. Quizá mi presencia le dejaba ver un puente, un lazo, un ancla, una posibilidad de que un mensaje desesperado llegara justo a quien le dio alumbramiento. No sólo deseaba escuchar la voz materna, sino entender las razones de la lejanía; no de aquélla provocada por la distancia espacial, sino de aquélla más aborrecida: la incomunicación y el silencio.

Me parece que una parte importante del análisis que ofrece el estudio de casos transnacionales de migración, que como en este caso contengan imágenes abstractas e impredecibles, se puedan ver las formas del mutamento cultural a través de momentos específicos de transición y negociación, en este caso establecidos entre madre e hija, entre Perú e Italia. 
Como preámbulo de nuestro encuentro dibujé a Miszka un mapa de Italia, y mientras lo dibujaba le decía que Italia era una bota. Luego me di cuenta de que no era claro por lo que proseguí dibujando un mapa del mundo. No perdía algún trazo. "Italia es una bota. A ver, nosotras estamos en el hemisferio americano, en América". 13 Aproveché para indicarle el país del cual yo provenía. "Yo soy de México. Digamos que esto es México, más o menos. Esto es México, Estados Unidos, Canadá [...]. Aquí está Groenlandia, Centroamérica y luego acá está Europa. Acá está Italia. Es una bota"14. Luego indiqué la ciudad en la que yo vivía en Italia. Quise decir el nombre de la ciudad en italiano, pensé que quizás era así como su madre se lo había dicho. Cuando dije Torino me interrumpió felizmente:

¿Tu mamá está en España? En Toledo me dijo que estaba. Toledo está por aquí. Y tu mamá, si dice que está en las montañas. (Mientras dibujo) Aquí hay una cadena montañosa como los Andes que se llaman Alpes, acá. Yo vivo aquí, en una ciudad que se llama Torino. (Me interrumpe con una voz más vivaz) iA Torino! Allí está mi mamá. Abíal lado! (indicaba en el mapa) iDice que se fue más allá de la España. Que Torino está al lado de las montañas. Está por la nieve mi mamá. [Queda por donde está la nieve]. Porque dice que nada más cuatro meses se había quedado en España. Después en junio se vino [se fue]. Después me dijo, de repente el otro año me regreso [a Perú]. "Sino encuentras trabajo mamá te vienes ${ }^{\jmath * c}$. Si tu mamá dice que está cerca de las montañas entonces está por aquí. (Le indico con un lápiz los Alpes en mi dibujo). ${ }^{15}$

Finalmente a través de esta imagen cartográfica pudo concretizar la imagen del país de emigración de su madre. Así fue que su primer comentario al respecto fue que nosotras vivíamos más cerca - si se toma en consideración México y Perú - y que su madre se encontraba más lejos.

13 Frase mía. Entrevista a Miszka (pseudónimo), realizada en lengua española en la escuela primaria privada femenina "Santa Rosa" de Trujillo, el 11 de noviembre del 2005 -Archivo areia.

14 Frase mía. Entrevista a Miszka (pseudónimo), realizada en lengua española en la escuela primaria privada femenina "Santa Rosa" de Trujillo, el 11 de noviembre del 2005 -Archivo areia.

15 De mi entrevista a Miszka (pseudónimo), realizada en lengua española en la escuela primaria privada femenina "Santa Rosa" de Trujillo, el 11 de noviembre del 2005 -Archivo areia. 
Esta imagen del mundo, así como la posición que ella ocupaba en él, le sirvió para recapitular la separación con una nueva forma de atravesar la experiencia dolorosa de la migración. Algo que no podemos afirmar es si en el mapa mental de la madre de Miszka se proyectaba la imagen de la migración interna peruana como premisa contenida en la memoria colectiva nacional o si bien los medios que tenía para obtener información acerca de la posibilidad de irse al extranjero.

Desde el momento que el dasarraigo toma forma, ella también dibujó un mapa después de nuestra entrevista. Me parecía que ahora la imagen que tenía de su madre era distinta. La imagen que a continuación muestro es básica para ella, se trata de una fotografía que probablemente aún no había podido ver, una foto de su mamá en Italia. A ella le bastaba una imagen cualquiera.

He querido mostrar la "filosofía" de la pequeña Miszka porque la consciencia acerca del evento migratorio se transforma en una visión de lo que se ha convertido el mundo con el paradigma global. ¡Cómo le hubiera gustado a la pequeña vivir en el norte peruano junto a su madre, sin tener que esperar el batido del viento esporádico con la voz de su madre a través del teléfono. La consciencia y la acción de hija abandonada la expulsaba del presente: Trujillo. Sin embargo, la experiencia migratoria la colocó en el centro de los acontecimientos nacionales. Resulta irónico que el mismo evento que la agobia le da la respuesta, pues a partir del entendimiento del sitio que ocupaba en todo esto pudo hilar a su tiempo y a lo que se encontraba fuera de él extrayendo de la memoria todo acerca de su madre siguiendo su trayectoria desde Perú hasta Turín. Me valgo de una reflexión de Chiara Vangelista que recoge los signos significativos que este testimonio familiar presenta: "La familia ya sea nuclear o alargada, es presentada como una entidad de la vida dotada de voluntad propia, casi como un actor histórico, cualitativamente diverso a la suma de las acciones, de los ideales y de los deseos de cada uno de sus componentes" (Vangelista, 2004, p. 507).

Su dibujo le dió fuerza para apaciguar el deseo incontrolable de volver a ver a su madre. Los graves problemas de comunicación con su padre la agobiaban tanto que el vacío de su madre era como parte de muchos vacíos. La posibilidad de no volver a verla afirmaba el desierto de vivir en una casa sin familia. El pasado era arbitrario y el presente era la búsqueda. Las experiencias del pasado comenzaron a fragmentarse pues 
cuando hablamos ya era otro tiempo, porque el pasado tal como había sucedido se reflejaba de manera diversa respecto al espacio y los espacios. Quizás la siguiente frase sintetice - en parte - lo que en su mente sucedía: "El discurso sobre el pasado [...] puede desarrollarse libremente siguiendo su lógica interna, sin tener que respetar las construcciones ideológicas del poder" (Feretti, 2003, p. 21).

Lo que se llama "darse cuenta" o "caer en cuenta" fue para Miszka un proceso que turbó particularmente su niñez. Como sabemos, ella no había visto ninguna imagen de su madre en Torino. Sin embargo, una era la grande satisfacción de Miszka; en sus manos estuvo - y fue claro y palpable - la búsqueda de la realidad verdadera. Ella misma se pudo procurar esa imagen que tanto deseaba ver. Aceptó entonces mi abandono y el inicio de una nueva lejanía del único - quizá - lazo creado por ella con su madre. Se quiso escribir mi nombre y en su pensamiento cancelar en el infinito próximo (su futuro) lo difícilmente definible: el abandono.

El testimonio de Miszka nos matiza los misterios del fenómeno migratorio. La migración no se manifiesta de la misma forma para todos. Son elementos importantes la edad, la historia personal, la historia de familia, la identidad de género desenvuelta. Y más: del conocimiento acumulado durante los años vividos.

Para Miszka la migración y sus motivos (justificación) - si es que éstos existían para ella - le eran incomprehensibles pues en sus manos, con su tacto, apenas un dibujo, un sólo recuerdo interiorizaba la figura materna. Me parece que con sus trazos y esbozos me pedía que regalase a su madre su dibujo para olvidarse del resentimiento que exteriorizaba durante toda su narración hacia la vida, hacia su nuevo mundo familiar: su padre, su hermano y su abuela.

Los diálogos de la entrevista con Miszka confluían en una foto que desmentía literalmente la condición precaria en la que vivía; es decir, sin su madre. En su mente la representación espontánea de allá (Torino) era "aquî", su madre estaba "aquî". Sólo una cosa no estaba "aquí", ella. Mejor dicho, todos los lugares, los tiempos que podía imaginar eran uno solo. El tiempo se había vuelto a su medida tan flexible como ella lo quería.

Dibujé, como ella, desde dentro de mi memoria, para trazar el regazo de su madre que me pedía, que por el momento para ambas era incierto e impreciso. Primero dijo Toledo en España, luego concluyó Torino. Todas sus conjeturas partían de los puntos cardinales del mapa-mundi. 
Buscaba y traía a su narración la avalancha de fragmentos. Algunos la traicionaban. Su tiempo finalmente se disgregó; su verdadero tiempo estaba en otra parte, separado de lo que había estado unido. Su tiempo estaba en ella misma, en su época, en Trujillo, en su escuela Santa Rosa, con su abuela, con su hermano y, aunque le expresara temor, con su padre.

Finalmente, si queremos asir lo dicho por Miszka a través de su dibujo es que la migración era para ella una amarga sensación; una emoción significativa que se asemejaba al abandono, pero que ahora comenzaba a olvidar para recapacitar sobre su vida. Sí, ella se convertía en lo más importante. La otra vida que se abría además de la de ella y su madre era la suya.

\section{Lejanía y memoria}

En el discurso de las madres dominicas de la inmaculada concepción de la escuela Santa Rosa, en la que estudiaba Miszka, la idea principal que favorecía mi interferencia directa en este caso escolar era el hecho preciso e indiscutible que yo provenía exactamente del país al cual la madre de la infante había emigrado. Empero quien me habían pedido el favor de hablar con la niña declaraba también otras motivaciones, los problemas de rendimiento y de concentración que presentaba la alumna en sus estudios. Interpretando esta serie de buenas intensiones, podemos decir que la esencia de idea de las monjas era acabar - de una vez por todas - con la sensación de lejanía que vivía Miszka.

En la experiencia migratoria, la lejanía y la memoria se manifiestan unívocamente, dado que la distancia respecto a los eventos a ésta adjudicados y la presencia física de los familiares que emigran se encuentran simétricamente equidistantes. Es decir, la distancia que separa los sitios, los espacios y los tiempos, terminan siendo fuente única de los procesos de vida. Para Miszka, la reconstrucción y explicación del movimiento migratorio corresponde a la yuxtaposición de sus propias construcciones simbólicas del evento, es decir, de los espacios con los sentimientos y los recuerdos. Esto también puede leerse como un ensayo que elabora nuvas 'pluri-pertenencias' (Salih, 2003). Los resultados pueden ser muy variados pues, como afirma Anne Marie Fortier: “...la cultura de la migración no es homogénea ni tampoco uniforme” (Fortier, 2000, p. 157). 
De ahí que, rotos los lazos familiares, la lejanía es posible leerla a través de las dinámicas que los mismos recuerdos de la memoria han ido desencadenando como parte del proceso identitario y de aprendizaje. Una fórmula de dicho proceso, con el cual concordo plenamente, es lo que Luisa Passerini ha denominado la "extensión de la inversión identitaria" (Passerini, 2008, p. 313), en parte indicado como fruto de los "procesos de identificación territorial" (Passerini, 2008, p. 312). Dichos elementos, ya sea el subjetivo-identitario que el subjetivo-territorial, se encuentran presentes en el caso de Miszka a través de la revisión exhaustiva que realiza de todos y cada uno de los traslados espaciales de la madre; espacio y cronología son un punto de partida para la niña. Luego, la falta de iniciativa y comunicación por parte de su madre la llevan a preguntarse acerca de las repercusiones de la migración en su familia y más tarde aún, a la negociación de nuevas deseables-indeseables relaciones familiares. Por así decirlo, éste es el proyecto o bien la "elección e inciativa para actuar" que emprende a partir de una visión infantil (Wartofsky, 1981, p. 199) en una atmósfera y condición de incertidumbre que la hacen dudar de la justa posición que ella misma tiene en su espacio originario, Trujillo.

La lejanía también se puede calcular siguiendo de cerca la memoria del pasado y sus proyecciones. Paul Ricoeur retoma la fórmula de Aristóteles "La memoria es del pasado" para explicar que la historia se expresa con términos de un léxico que introduce y habla acerca de la memoria "como un protector de la distancia temporal" (Ricoeur, 2003, pp. 5-7); una imagen del pasado como el transitar de sí mismo. ¿El pasado, es memoria y la memoria es el lenguaje del pasado? Para responder esta pregunta tendremos que acercanos al carácter del yo y, a su lenguaje. Al pasado habrá que considerarlo como la acción continua ("metástasis" de la historia), como una variable que da movimiento a la naturaleza de la diversidad cultural; de la acumulación de otros conocimientos culturales. Tanto para la madre como para la hija, los traslados migratorios conllevan a la relación con la alteridad, ya sea como sujeto migratorio que como sujeto indirecto de esta experiencia.

$\mathrm{El}$ sentimiento de pertenecia cultural, es una imagen que asemeja a la de una tela burda, o bién a una falda con todos sus pliegues. ${ }^{16}$ En el

16 Esta imagen se inspira a las faldas tejidas y bordadas que mujeres de grupos indígenas de la serranía peruana confeccionan para ellas y para sus hijas. En particular las faldas con telas hechas a mano utilizando telares de cintura. Esta imagen me es útil para explicar la experiencia manual que las hace bordar y narrar con más seguridad. 
contexto de las migraciones actuales dicha complejidad reside en el compromiso cultural que nace de la consciencia y de las consecuencias de esta movilidad en donde vive la idea "a propósito del potencial de las muejres para la construcción de una Europa culturalmente abierta y múltiple" (Passerini, 2009, p. 85).

La distancia y lejanía que ahora determinaban la relación con su madre correspondía para Miszka a la misma distancia que se establecía entre ella misma con su identidad. El lenguaje suyo cotidiano, se había ido reduciendo hasta tener que hablar sólo de la partida de la madre ("la memoria cronólogica: la memoria calculadora") (Borgna, 2009, p. 137); hecho que le mostraba de manera intrínseca la alteridad. Allí, en medio del momento en el cual se alambró el muro impenetrable de la lejanía, desencadenó una crisis identitaria asimismo desdoblable en una serie de errores causados por la verdad oculta o bien por la ausencia de respuestas incluso a las dudas más simples, como por ejemplo, una imagen o fotografía de la madre en Toledo y en Torino. A Miszka le faltaban estos datos visuales sin los cuales le era imposible distribuir adecuadamente la lejanía que equidistaba de cada miembro de la familia respecto la madre y de cada uno respecto los diferentes espacios a los cuales cada quien se trasladaba.

No me resultaba muy claro, incluso después de que hablamos, con quién vivía. Pues si bien indica como las personas más importantes con las que convive todos los días, la abuela materna, el padre y el hermano mayor, su narración no precisa este aspecto. Miszka cuenta que vivía con la abuela paterna en Trujillo junto a su hermano mayor, su padre en cambio iba a visitarla siempre - sobre todo a la hora de la comida -; su hermano estaba estudiando y casi nunca estaba en casa. Mientras que los abuelos maternos, personas muy queridas para ella, vivían en un pueblo aledaño a Trujillo de nombre Virú. Lo que dice es que su mamá la dejó encargada con sus abuelitos.

A propósito de crisis identitaria Ricoeur menciona tres aspectos que podríamos aplicar en nuestro análisis y caso: “[...] ante todo ésta deriva la relación con el tiempo, y más precisamente con la permanencia de sí mismo a través del tiempo. Una segunda fuente deriva de la competición con los otros, con las amenazas reales o imaginarias de la identidad, a partir del momento en que ésta se confronta con la alteridad, con la diferencia" (Ricoeur, 2004, p. 71). Un primer elemento que se puede sobreponer a la crisis identitaria de Miszka causada por el fenómeno de la migración es la 
relación que establece con el tiempo al cual podemos dar un valor de descontinuidad y ruptura. El segundo aspecto, es la capacidad de imitación o de convivencia con los otros para imaginar la identidad propia, aspecto que carece de bifurcaciones, pues no menciona ninguna relación con sus compañeras de escuela, es decir, ninguna anécdota de este tipo. El eje central narrativo se mantiene en la comparación de las condiciones de vida de la madre y de ella.

Mérito de este caso, es que inclusive en condiciones de fuerte incomunicación se abren nuevas dinámicas y relaciones familiares. En un sentido general y amplio podemos considerar a las dinámicas entre los hijos y sus padres migrantes, un tipo de prácticas transnacionales.

Un primer aspecto a resaltar es que la visión transnacional de Miszka depende de su madre y se mantiene estrictamente relacionada con las historias de migraciones que va acumulando en el tiempo la figura materna, es decir hacia Trujillo y hacia Turín. En este sentido, el constante enfrentamiento de ella con la alteridad da como resultado un concepto del espacio global estrictamente relacionado con sus derechos de niña y de hija. Y más: reunificación. La única fidelidad de Miszka, demostrable a través del texto de su carta y del dibujo a la madre, es el amor de hija que desea pueda desbordarse en una nueva dirección ya no local, sino transnacional de sí misma y de su mundo. Y más: familia.

Empero, por otro lado, la consciencia de ser una niña le permite inter-relacionarse con un universo más amplio, dado que a la infancia se le identifica y atribuye una visón universal (James et al, 2002, p. 169) y, por ende, transnacional. Como señala James: "I bambini sono una categoria strutturale, fanno parte della reale costruzione della vita sociale e devono, per ciò, essere considerati una forma integrata in tutti i sistemi" (James et al, 2002, p. 169). No es sino hasta este momento que ve a su familia con otras cualidades; si su familia toma estas características transnacionales es por la importancia que tiene para ella la relación entre madre e hija.

\section{Autoretrato de género}

Más que las estadísticas, deberían golpearnos los hechos. Una mujer, madre de familia que se ve obligada a dejar a sus hijos. Un hombre, pareja, padre de familia inexistente. Los cuerpos femeninos asomándose afuera, 
lejos y a solas. Como nuevo origen y motor del fenómeno de las migraciones actuales hay alguien que se auto-propone repetidamente, la figura materna.

Como señalaba Silvia Salvatici en su ponencia titulada De prófugas a ciudadanas? Trayectorias del resettlement en Europa de la segunda postguerra presentada en el seminario Femmes pour l'Europe (2009), la migración escoge mujeres que presentan ciertas características, con un perfil funcional no sólo para el mercado de trabajo sino también para la sociedad de llegada, o sea de 18 a 45 años de edad, buena salud, solteras, viudas o sin hijos. En suma, personas que viajan solas y por poco tiempo. Esta misma imagen la encontramos en el caso del éxodo femenino de ecuatorianas hacia Europa (Génova y Madrid) descrito por Chiara Pagnotta: "Las mujeres viajan solas y conforman el primer anillo de la cadena migratoria siguiente" (Pagnotta, 2008, p. 359).

En el caso de Turín, ciudad final de emigración de nuestro case-study, la comunidad peruana la conforman sobre todo mujeres solteras o madres de familia ${ }^{17}$. Veamos la siguiente opinión respecto a la migración actual expresada por una mujer peruana soltera residente en esta ciudad desde el '95 a quien entrevisto luego de primer viaje de regreso a Perú después de 10 años:

En el pueblo joven ${ }^{18}$ en donde vivía hay muchas personas que se han ido. [...] He notado que ahora más que nada se van las mamás por el hecho que saben que para una mujer es más fácil encontrar trabajo que los hombres. Primero llegan al extranjero las mamás. Las mamás trabajan, logran ahorrar para después financiar el viaje del esposo y después los hijos. Los hijos vienen por último cuando ya los padres han conseguido una casa y tienen trabajos más seguros. ${ }^{19}$

17 De una población total de 6,018 personas, 3,724 eran mujeres de las cuales 2, 232 eran mujeres solteras, 1,393 eran mujeres casadas y 60 eran viudas. Los datos corresponden a los residentes regulares hasta el 31 de diciembre del 2006 y fueron eleborados por la oficina de población y estadística de esta ciudad.

18 Es significativo que su lugar de procedencia lo indique con el concepto de pueblo joven o barriada, que indica que en su familia vivieron experiencias de migración interna. En este caso el pueblo joven al que se refiere Natalia es Villa María del Triunfo en Lima.

19 De mi entrevista a Natalia (pseudónimo), realizada en lengua española en Turín el 5 de septiembre del 2005-Archivo areia. 
La descripción de Natalia ${ }^{20}$ y el caso de la madre de Miszka ofrecen una síntesis de experiencias típicas que pueden reproducirse a nivel colectivo. Ambas demuestran cómo el evento migratorio y en general la actual diáspora peruana se encuentran en manos femeninas. Y no sólo, pues "la mamá que emigra" es la protagonista del mito migratorio y evidencia un autoreconocimiento por parte de ellas como mujeres jefes de familia. Esta idea revela como sea de gran valor, en el imaginario colectivo femenino peruano, emprender una experiencia migratoria.

El relato de Miszka sobre la relación con su madre podríamos considerarlo de tipo retrospectivo por la insistencia que demuestra la niña en su relato de comparar las condiciones femeninas de cada una de ellas en familia y en general que cada una ha vivido en Perú. Empero, su testimonio sugiere la configuración de la memoria individual elaborada a partir sobre todo de las relaciones familiares. Esta idea se complementa con lo que escribía Pierre Bourdieu acerca de la organización social a través de la familia, es decir que la familia representa un común denominador, un principio reconocido y primordial en la matriz social en general, una "estructura mental individual y colectiva" (Bourdieu, 1995, pp. 123-124).

En cambio, el sentimiento de pertenencia a la patria peruana la representa a través de la capacidad de mostrarse a sí mismas en contextos públicos y privados. Reelabora la imagen emancipatoria femenina a través de emociones íntimas como el llanto. Otorga justo a este momento catártico un espacio femenino de emancipación. Es así que reconfigura el autoretrato identitario de género, subrayando la siguiente fórmula: quien llora a escondidas aún no es una mujer emancipada.

A sus ocho años, pudo darse cuenta del pasado sinuoso que rompió el encanto de su familia; la nueva imagen sobre esta cuestión entre ella y su madre, hecho de su puño y letra, la sorprendió hasta el punto de sentirse cambiada. Pues no fue sino después de haber visto el mapa de su madre hecho por ella misma cuando comenzó la búsqueda. Ante todo, la modernidad que la migración debería llevarle hasta la puerta de su hogar con el puente intermediario presente entre su abuela y entre ella y, entre ella y su madre: las remesas económicas.

20 Para una revisión exhaustiva de los temas que propone este case-study véase mi ensayo La traiettoria migratoria di una famiglia del 'pueblo joven' Villa María del Trionfo: da Ayacucho alle 'barriadas' di Lima, a Torino (1995-2006). Studi Emigrazione, n. 170, 2008, pp. 377-392. 
Es a la abuela materna que vive en Virú, Zona La Libertad del norte peruano, a quien la madre manda el dinero y es ella misma quien lo distribuye a la familia de Miszka, al padre y al hermano. Muy probablemente, en el primer periodo las remesas económicas fueron enviadas al padre, esto es lo que se deduce del siguiente fragmento de su narración:

Yo hubiera vivido acá con mi papá y mi mamá juntos pero no se puede porque mi papá nunca deja [de insultar a mi mamá] A veces mi papá manda a la mierda mi mamá. Disculpa la palabra. [Cuando mi mamá le dice a mi papá] "¿Porqué tu no pones la mitad para mi hija? Yo pongo la mitad y tú pones la mitad". Y entonces [mi papá] le dice: “¡Entonces tú vete a la mierda!”. Él me quitó el teléfono. Y yo y mi hermano nos pusimos a llorar. ${ }^{21}$

El momento tremendo y violento que recuerda nos da la idea de una pérdida del control de la madre respecto a su familia. Por otro lado, la madre intenta desmesuradamente de cambiar desde la raíz las modalidades de participación a la economía familiar, no perdiendo nunca de vista el rol que, desde que se convirtió en sujeto migratorio, tuvo que desempeñar o ampliar.

Para percibir con otros alcances y potenciales el caso de la pequeña es menester tener presente la siguiente reflexión acerca de la figura infantil en la sociedad y en la historia pues "el ser niño significa ser estático porque también éste existe en el tiempo, forma parte, como todos los actores sociales, de la historia" (James, 2002, p. 167). Precisamente, la facultad de Miszka de apropiarse de una nueva identidad de género reside en el mérito de acercar la memoria peruana y sus vivencias (memoria interior) con sus vicisitudes (la sombra de la memoria de familia). Según el concepto de Joan W. Scott: "El núcleo de la definición radica en la conexión integral entre dos proposiciones: el género es un elemento constitutivo de las relaciones sociales basadas en diferencias percibidas entre los sexos, y el género es una forma primaria de relaciones significativas de poder" (Scott, 1988, p. 42).

21 De mi entrevista a Miszka (pseudónimo), realizada en lengua española en la escuela primaria privada femenina "Santa Rosa" de Trujillo, el 11 de noviembre del 2005 -Archivo AREIA. 
En este sentido, las reflexiones que elabora poseen un alto nivel de análisis pues da razón de los elementos constitutivos de las relaciones entre los diferentes sexos y analiza las relaciónes de poder a partir de una imagen móvil femenina que radica - en parte - en la motivación del origen de la partida de la madre.

Una vez distinguidos los tipos de las relaciones, se establece así una cronología de vivencias, de olvido y de búsqueda; intento de reconstrucción y de erradicación de recuerdos aborrecidos. A partir de la intromisión indirecta del fenómeno de la migración, experiencia que traducía la madre a todos los componentes, las memorias de familia contendrían recuerdos más complejos respecto a lo que había antes constituído la historia familiar originaria. En cada uno quizás no percibido de la misma forma; probablemente aquí la visión de género entra en juego. Dicho con una frase de Octavio Paz: "el reconcimiento del otro y del otro. La traducción es una actividad civilizada porque nace como la imitación, de la veneración ante lo ejemplar o lo único" (Paz, 1994, p. 77).

En la misma dirección encontramos la reflexión de Domenico Jervolino acerca de la filosofía de la traducción que habla de la traducibilidad de saberes y de lenguajes (Jervolino, 2008, p.10), en este caso aplicado a la traducción de un evento migratorio en familia, como el cúmulo de un conocimiento que puede transmitirse o bien que puede constituir un lenguaje pronunciable, en el que se vierten actitudes sociales.

Quizás en el fondo de las ideas de Miszka sea su percepción respecto a la necesidad emancipatoria de la madre. Es probable que esta idea le susurrara al oído que la única salida que tenía era la de irse, salirse de su casa. Sin embargo, latente y viva es la sublime prueba de amor expresada por Miszka para sí misma y para su madre. Así la tocaron con sus propios trazos y sus letras; "lenguaje de un trágico expresionismo" (Borga, 2009, p. 179):

Trujillo, 11 de noviembre del 2005

Querida mamá:

Te quisiera decir que te extraño mucho, y con ese problema que tuvimos creo que no me hablas, yo quisiera que en Italia no llores. Al contrario, quisiera que estés alegre para yo estar alegre. Mi hermano y yo te queremos mucho pero hasi quisieramos nosotros 
que tu nos quisieras mucho. Por eso te quiero decir

que estoy bien de salud igual mi hermano,

derrepente tu estas bien de salud también.

Me voy despidiendo de ti porque te quiero decir

que vengas muy pronto mami. Yo y

mi hermano te extrañamos. Chau. U. U. U.

Tu querida hija Miszka 22

Las imágenes del exterior y de las relaciones familiares también fluyen, no de manera casual, sino incluso de manera interdependiente. Veamos una reflexión de Joan W. Scott acerca del significado inminente respecto la asimilación de las relaciones de género que, al mismo tiempo, expresa la rapidez con la que se simplifica nuestro mundo: "Más a menudo queremos saber cómo ocurren las cosas con el fin de averiguar por qué ocurren [...] para ello tenemos que lidiar con el sujeto individual así como con la organización social para articular la naturaleza de sus inter-relaciones, pues ambos son cruciales para comprender cómo funcionan los géneros y cómo se producen los cambios" (Scott, 1988, p. 42).

Precisamente, un elemento interdependiente que encontramos en la carta de Miszka a la madre es la identificación de una condición femenina precaria al interno de su familia y de la generación a la que su madre pertenece en la sociedad peruana. Cuando Miszka escribe: "[...] yo quisiera que en Italia no llores", de esta frase surge explícita su persuación respecto a la identidad de género pues define la amplia distancia y diferencia, especialmente respecto a la forma de vivir las emociones que se relacionan con los géneros.

En este sentido, la identidad de género se presenta como una dicotomía, una característica que si quisiéramos aproximarla al estudio de una posible diversidad en este ámbito por parte de las generaciones, encontraríamos las mutaciones, así como las diversas connotaciones de percibir las relaciones de género. Veamos algunos aspectos de la vida cotidiana descritos por Miszka acerca de la identidad y las actitudes de género:

A veces mi papá me da miedo, me da como temor. Pero mi mamá no, mi mamá era siempre alegre. Pero yo me he dado cuenta que

22 Carta de Miszka a su madre. Trujillo a 11 de noviembre del 2005. 
mi mamá cuando llora lo hace a escondidas. Pero no es libre, es a escondidas. Toda mujer lo hace a escondidas. Y yo no lo hago a escondidas. $^{23}$

El fragmento de la narración esboza desmesuradamente y con claridad el ámbito más íntimo de las relaciones que se viven en su familia. Es visible, la presión que ejerce en ambas el padre, como también lo es la sensación de encierro, de negación del género femenino con la descripción del llanto a escondidas de la madre. Sólo en muy contadas ocasiones la intimidad emotiva debe esconderse incluso de la hija. Esa idea que da Miszka dell llanto de su madre que no se asoma a la vista de los otros es significativo, pues lo compara con todas las mujeres peruanas cuando dice que "toda mujer lo hace a escondidas". En el lenguaje que utiliza para describir la relación con su madre encontramos asimismo "un conjunto de relaciones" que a su vez "contiene la posibilidad de la negación, la resistencia, la reinterpretación, el juego de la invención metafórica y la imaginación" (Scott, 1988, p. 42). Sabía que era una niña, pero también que su riqueza estaba allí precisamente, en ser una mujer. En efecto, el diálogo con la madre se concentra en el aspecto de la negociación de la identidad de género que ella traduce en la imagen del llanto.

Por otro lado, la generación de los niños de la migración fuertemente atravesados por la lejanía y el abandono encuentran reparo tanto ellos como sus familiares gracias a los espacios digitales. Como ya ha señaldo Sassen Saskia, la existencia de espacios digitales globales son un ambiente social emergente ${ }^{24}$ o bien forman parte del ámbito social (Sassen, 2008, p. 227). En este tipo de espacios confluyen el "espacio real" con el "espacio digital". En algunos casos que he estudiado de madres peruanas residentes en Italia, los espacios digitales son utilizados por ellas para comunicar con sus hijos y constituyen un espacio real de los momentos familiares, así como también en las relaciones de género que se activan y

23 De mi entrevista a Miszka (pseudónimo), realizada en lengua española en la escuela primaria privada femenina "Santa Rosa" de Trujillo, el 11 de noviembre del 2005 -Archivo areia.

24 Para profundizar este tema véase sobre todo el capítulo octavo Formazioni globali emergenti e indicazioni di ricerca, del volúmen de Saskia Sassen. Una sociologia della globalizzazione (título original A sociology of globalization). Torino: Einaudi, 2008, pp. 209 - 234. [Norton \& Company, 2007] 
refuerzan - en particular - aquellas relaciones que se establecen entre madre e hijos; premisas básicas para la transmisión educativa ${ }^{25}$.

Miszka y su madre, como hemos podido ver, han podido comunicarse a través del silencio e la invisibilidad a través de un espacio transnacional en proceso de ser descubierto e incluso ensayando diálogos de gran complejidad en terrenos delicados de la esfera intersubjetiva femenina.

\section{La imagen de Europa}

A diferencia de la imagen que prevalece en el imaginario colectivo peruano, de percibir a Europa como un bloque único, para Miszka Europa no tenía aún un trazo preciso, sino la forma más abstracta e incomprensible como la partida de la madre. Quizás por esto, durante nuestro diálogo, yo personifiqué este territorio, pues provenía directamente del mismo lugar donde se encontraba la madre. Llegaba de Turín, de Italia, de Europa. Para la niña fuese irrelevante que en mi caso Italia no representara mi verdadero origen, ella confiaba en mi efectiva presencia en Turín, ciudad que nos unía profundamente en una correspondecia geográfica para ella imaginaria, para mí real.

Después de haber terminado el mapa del mundo, me pareció de percibir que para ella era Europa en persona. La mirada de Miszka veía en mí un demonio, era el demonio, o bien, la ninfa que se había raptado su madre para llevársela lejos de ella. Aquella emoción de abandono era tan profunda que le resultaba imposible erradicarla. Había hecho la prueba de volverse a ver con la madre, por lo menos a través de una llamada telefónica, sin embargo esto no era posible porque su hermano mayor era el único que tenía el número de teléfono, ella era demasiado pequeña para manejar esa información delicada.

A veces cuando mi papá no está en la casa y habla mi mamá habla conmigo y me dice: "Yo te extraño hijita". Porque a veces dice

25 Sobre el tema del uso del espacio digital para la continuidad de las relaciones y la emotividad en el caso de la diáspora peruana en Italia véase mi paper Emozioni, linguaggi e memorie collettive nella migrazione femminile dal Perù all'Italia ensayo presentado en ocasión del seminario titulado Donne attraverso l'Europa de la Tercera Leccióne Anual Ursula Hirischmann del ciclo Femmes pour l'Europe sobre "Género y Europa”, mayo del 2009. 
que cuando yo me pongo triste ella lo presiente, lo siente. Entonces yo le digo: "Mamá no te preocupes yo voy a estudiar y voy a terminar y voy a ayudarte en todo". "Sí hijita haz lo que tu hermano te diga estudia por favor hijita". Mi mamá mucho siempre llora, se pone mal a veces cuando llora. Y yo le digo mamá no te preocupes, por la cólera también que tiene. No está tan alegre, nos extraña. (Entrevista a Miszka)

La situación de vida de Miszka parecía ser precaria desde el punto de vista de la serenidad emotiva debido a algunos conflictos entre sus padres, quienes se habían separado y vivían cada uno su vida por su lado. Ella hubiese querido tener una familia unida. Por este motivo, para ella Europa personificaba un elemento desintegrador.

Quiero estar contigo hermano, no quiero que tú también te vayas hermano a Europa. "Es que yo no puedo con mi universidad. Cuando yo termine la universidad, vénte, nos vamos a vivir a otro lado. Cuando mi mamá venga va a comprar un departamento." (Idem)

El lugar Italia y el lugar Europa para Miszka tienen un mismo significado: son los culpables del abandono de su madre y de la posibilidad que su hermano pueda también alejarse de ella. Según su narración, no sólo Italia ha alejado su madre, sino que ha transformado su personalidad, la emotividad de su mamá:

Me acuerdo mucho cuando mi mamá me acariciaba cuando mi mamá me ayudaba mucho en mis tareas aunque no supiera. Mi mamá siempre era responsable de mí. Me llevaba al mercado de mi abuelita. Así cariñosa era mi mamá. Pero cuando se fue a Italia mucho ha cambiado porque ya nos grita nada más. Nos habla nada más con voz fuerte. Y luego me dice " $\mathrm{N}$ No tienes que reclamar nada, yo te doy todo". (Idem)

Miszka intercambia Italia, España y Europa como si se tratara del mismo sitio, un único lugar. Insiste mucho sobre las implicaciones culturales: su madre cambió desde que se fue a España y vive en Italia y no 
quiere que su hermano cambie yéndose él también a Europa. Cuando se declara una mujer muy diversa a su madre porque ella no esconde sus emociones y no llora a escondidas, la identidad femenina emerge de la relación establecida sobre todo con las figuras femeninas de la familia de origen más cercanas así como también de la condición general de la mujer en Perú. Podríamos exagerar diciendo que la pequeña Miszka se declara una mujer europea cuando dice distinguirse de las demás mujeres peruanas por la forma en que expresa su llanto, sin cuidarse de los confines, sin restricciones.

Para la preparación de este ensayo volví a escuchar nuestra entrevista y entendí que a causa de aquella emoción de abandono, no sólo Europa era invisible para ella sino todo el mundo. La emoción que le restituía la lejanía de la madre, la cegaba ofuscando en ella cualesquiera capacidad de dirección y cada ensayo de orientación. Volver a escuchar nuestras voces, nuestros diálogos, me brindó una nueva visón del significado que para ella tenía mi presencia. Creo haber personificado más de cuanto imaginaba. Probablemente no personificaba ní Europa, ní Torino, ní los Alpes, ní la nieve, pues era de alguna forma una imagen muy cercana o parecida a su madre. En el fondo, de Europa - la madre - regresaría ya no siendo la misma.

A través de este mecanismo filosófico mental, Miszka aprende a reconocer a Europa, Italia y España dándoles una connotación espacial, empero también y sobre todo emotiva. La experiencia de la pequeña Miszka nos enseña que es indispensable tener la consciencia espacial de nuestras vidas, experiencias y emociones a éstas enlazadas, ya que la imagen de Europa que emerge es a través de los traslados emprendidos por su madre hacia lugares cercanos entre sí en Europa. La indicación de la nieve representa los confines. La madre está cerca de la nieve. Interpretando a Miszka, Europa reside en la acción misma de moverse y trasladarse a lugares cercanos/vecinos. La imagen de la Europa de hoy yace entonces en el acto mismo de atravesar espacios, es decir, atravesar ya sea físicamente o mentalmente las naciones que la constituyen.

En la imagen de Europa de Miszka encontramos una metáfora adoptada por las discusiones actuales sobre la construcción de sentimento europeo. Teniendo en consideración cuanto señala Luisa Passerini que: "[...] las formas europeas de pertenecer a Europa pueden sólo identificarse en una perspectiva global" y que "el mito odierno de Europa ya no pertenece únicamente a nuestro continente ni tiene que ver exclusivamente 
con él" (Passerini, 2009, p. 119). La idea de Passerini sugiere que el viaje incansable hacia Europa puede ser emprendido inclusive no a través del traslado físico sino también es posible emprenderlo a todos aquellos que por algún motivo dirigen su mirada hacia este territorio, desde diversos lugares y cosmogonías. En este sentido tanto Europa como el resto del mundo está por todas partes.

\section{Conclusiones}

El nexo entre oralidad, visualidad y escritura, la narración y los silencios de los eventos, son la muestra excelsa de la amplitud y los recursos incansables que la historia oral contiene. El case-study de la niña peruana Miszka de 8 años representa la visión infantil de las consecuencias del fenómeno de las migraciones actuales permeadas de silencio y lejanía. Empero, sobre todo deja ver una "cultura de la movilidad", que se ha ido radicando en el horizonte femenino de la sociedad peruana y también nos habla de sus manifestaciones entre los confines y las ideas de dos mundos.

Otra imagen que restituye es la de pasividad respecto el futuro, detenimiento del crecimiento personal y social debido a una nueva mediación en su vida: la migración. A través de una historia migratoria de familia es posible entrever los momentos de unión y de ruptura de las releciones de género, los elementos tangibles y aquellos del terreno subjetivo en un espacio y tiempo preciso.

Por otro lado, la historia de Miszka hace emerger aspectos de resonancia poco considerados en el análisis y en el estudio de las migraciones actuales, los derechos, los deseos y las necesidades que estos actores de la migración desencadenan en toda la trayectoria de los padres. A estos aspectos se tiene que agregar que para poder reconstruir las características de esta generación de niños y jóvenes caracterizados por la amplitud de puntos de referencia (internos y externos), es necesario dilucidar las prácticas transnacionales que éstos activan: la educación a distancia, la negociación de la identidad de género, la intersubjetividad generacional e intergeneracional, el uso de espacios digitales, las remesas y la hibridización cultural.

Finalmente, la decisión de emigrar es un acto complejo que no sólo es producto de la conjunción de varios factores socio-económicos, de re- 
laciones de género, de la necesidad y búsqueda de producción cultural. La decisión de emigrar es también la prueba que demuestra la capacidad que presentan algunos individuos para solucionar los problemas cotidianos de la sobrevivencia. Desde este punto de vista, la migración aparece como una herramienta externa que algunos llevan a cabo dada la inexistencia de recursos en su realidad local. Dicho en otras palabras, decidir emigrar es ver hacia fuera de sí mismo, hacia fuera de su contexto empero quizá no hacia fuera de su familia. Me parece que, a la migración, hay que explicarla no sólo con otros conceptos sino también a través de las imágenes narradas que por éste fenómeno manifiestan sus actores y receptores.

\section{Referencias bibliográficas}

A.A. V.V. Retrato de la familia peruana. Niveles de vida. Lima: Instituto Cuánto; Unicef, $1994-$ 1996.

Altamirano RUA, Teófilo. Éxodo. Peruanos en el exterior. Lima: Fondo Editorial de la Pontificia Universidad Católica del Perú, 1992.

ARGUEDAS, José María. La sierra en el proceso de la cultura peruana. Formación de una cultura nacional indoamericana. México: Siglo veitiuno editores, 1977.

BORGNA, Eugenio. Le emozioni ferite, Milano: Feltrinelli, 2009.

BOURDIEU, Pierre. Ragioni pratiche (título original Raisons pratiques. Sur la théorie de l'action). Bologna : Il Mulino, 1995. [Paris: Édition du Seuil, 1994]

BONI, Federico. Media, identità e globalizzazione. Luoghi oggetti, riti. Roma: Carocci, 2005.

DESCARTES, Rene. Les passions de l'âme e Lettere sulla morale. Bari: Laterza, 1954.

FERRETI, Maria. Percorsi della memoria: il caso russo. Passato e presente. Franco Angeli, Vol. XXI, n. 59, 2003, pp. $17-36$.

FORTIER, Anne-Marie. Migrant belongings: memory, space, identity. Oxford; New York: Berg, 2000.

GOLTE, Jürgen et al. Los caballos de Troya de los invasores. Estrategias campesinas en la conquista de la gran Lima. Lima: Instituto de Estudios Peruanos, 1990.

HALBWACHS, Maurice. La memoria collettiva (título original La mémoire collective), (Comp. Paolo Jedlowsky, con un comentario de Luisa Passerini). Milano: Unicopli, 1987. [Paris: Press Universitaire de France, 1968]

HALL, Stuart. In but not of Europe: Europe and its myths. Passerini, Luisa (Comp.). Figures d'Europe. Images and myths of Europe. Bruxelles: P. I. E.-Peter Lang, 2003, pp. 35 - 46.

HENGST, Heinz et al. Per una sociologia dell'infanzia. Milano: Franco Angeli, 2004. 
HERNÁNDEZ NOVA, Leslie Nancy. Emozioni, linguaggi e memorie collettive nella migrazione femminile dal Perù all'Italia ensayo presentado en ocasión del seminario titulado Donne attraverso l'Europa en la mesa redonda de la Tercera Lección Anual Ursula Hirischmann del ciclo Femmes pour l'Europe sobre "Género y Europa”: Università degli Studi di Torino, mayo del 2009.

Irse. Donne peruviane a Torino (1985-2005). Storie di migrazioni. Quaderno di Storia Contemporanea. Istituto per la storia della resistenza e della società contemporanea in Provincia di Alessandria, n. 40, 2006, pp. 137-169.

JAMES, Allison et al. Teorizzare l'infanzia: per una nuova sociologia dei bambini (título original Theorizing (hildhood) trad. Fatima Farina. Roma: Donzelli, 2002 [London: Polity Press, 1997]

JAUSS, Hans Robert. Tempo e ricordo nella Recheche di Marcle Proust. Firenze: Le lettere, 2003.

JOUTARD, Philippe. La légende des Camisards. Une sensibilité au passé. París: Editorial Gallimard, 1977.

JUNG, Carl Gustav. Il problema psichico dell'uomo moderno. Il problema dell'inconscio nella psicologia moderna (título original Seelenprobleme der Gegenwart, Gesammette Werke, Band IO). Torino: Einaudi, 1994, pp. 276 - 300. [Olten; Walter Verlag, 1942]

ONG, Walter J. Oralità e scrittura. Le tecnologie della parola. Bologna: Il Mulino, 1986.

ORELLANA, Marjorie Faulstich, et al. Transnational Childhoods: The Participation of Children in Processes of Family Migration. Social Problems, Vol. 48, n. 4, 2001, pp. 572591.

PAGNOTTA, Chiara. L'emigrazione ecuadoriana: un'analisi di genere. Studi Emigrazione. N. 170, 2008, pp. 359-376.

PASSERINI, Luisa (Comp.). Identità culturale europea. Idee, sentimenti, relazioni. Firenze: La Nuova Italia, 1998.

"notre mère l'europe". Giorgina levi e Heinz Arian. Storie d'amore e d'Europa. Napoli: L'ancora del mediterraneo, 2008, pp. 279 - 316.

.Il sogno di Europa. Torino: Rosenberg \& Sellier, 2009.

. (Comp.). Storia orale. Vita quotidiana e cultura materiale delle classi subalterne. Torino: Rosenberg \& Sellier, 1978.

PAZ, Octavio. Obras completas. Tomo 3: Fundación y disidencia. México, D.F: Fondo de Cultura Económica, 1994.

PONIATOWSKA, Elena. Luzy luna. Las lunitas. México: Ediciones Era, 2a ed., 2007. [1994]

QVORTRUP, Jens (Comp.). Structural, historical, and comparative perspectives. UK: Emerald, 2009.

RICOEUR, Paul. La memoria, la historia, el olvido (título original La memoire, l'bistoir, l'oubli). Madrid: Editorial Trotta, 2003. [Éditions du Seuil, 2003]

.Ricordare, dimenticare, perdonare. L'enigma del passato (título original Das Rätsel 
der Vergangenheit. Erinnern - Vergessen - Verzeihem, Göttingen). Bologna: Il Mulino, 2004. [Wallstein, 1998]

SALIH, Ruba. Gender in transnationalism: home, longing and belonging among Moroccan migrant woman. London; New York: Routledge, 2003.

SALVATICI, Silvia, Da profughe a cittadine? Percorsi del resettlement nell'Eurupa del secondo dopoguerra, paper presentado en ocasión del seminario titulado Donne attraverso l'Europa en la mesa redonda de la Tercera Lección Anual Ursula Hirischmann del ciclo Femmes pour l'Europe sobre "Género y Europa": Università degli Studi di Torino, mayo del 2009.

SARTRE, JEAN-Paul. Esquisse d'une théorie des emotions. Paris: Hermann, 1995.

SCOTT, Joan Wallach. Gender and the Politics of history. New York: Columbia University Press, 1988.

TAMAGNO, Carla. Los peruanos en Milán: Políticas de identidad y producción de localidad. Carlos Iván Degregori (Comp.) Comunidades locales y transnacionales. Cinco estudios de caso en el Perú. Lima: Instituto de Estudios Peruanos, 2003, pp. 319 -389.

VANGELISTA, Chiara. L'individuale e il collettivo nelle interviste biografiche. Note a margine di un'esperienza brasiliana. Maria Melena Menna Barreto Abrahão (Comp.). Aventura (auto)biográfica. Teoría e empiria. Porto Alegre: EDIPUCRS, 2004, pp. 487-530.

VARGAS PUNCH, Eduardo. Sociología de la violencia. Posmodernidad y conflicto en el Perú 19802000. Lima: Gráficos S.R.L, 2004.

WARTOFSKY, M. The child's construction of the world and the world's construction of the child: from historical epistemology to historical psychology. Kessel, F.; Seigal, A. (Comp.). The child and other cultural inventions. New York: Praeger, 1981, pp. 88-215.

Resúmen: Este ensayo analiza el case-study de una niña peruana de 8 años de edad originaria de Trujillo, quien se separa de su madre cuando ésta decide emigrar a Toledo en el 2002. Su narración autobiográfica reconstruye el mapa mental migratorio que ambas emprenden desde el punto de vista de las relaciones familiares a través de dibujos y una carta dirigida a la madre que se encuentra en Turín. En esta historia de vida, el uso de la memoria individual y colectiva son fundamentales para llevar a cabo el proceso de negociación de la identidad de género, también útil para verificar los cambios identitarios que la madre sufre y que trasmite o calla - desde Europa - a su hija. La separación y el silencio entre madre e hija esboza descontinuidades, espejos rotos de una identidad de género que tiene que reproducirse a través de la memoria y que tiene un nuevo punto de partida, un mapa migratorio apartado e indecifrable en el cual es posible entrever las nuevas generaciones.

Palabras claves: identidad de género transnacional, experiencia migratoria, memoria, intersubjetividad, relaciones de género, mapa mental, Europa.

Transnational relationships between daughter and mother. The negotiation on gender identity across a migration live story from Peru to Europe

Abstract: This essay analyzes the case-study of a Peruvian girl of 8 years old originally from Trujillo, who is separated from her mother when she decided to 
emigrate to Toledo in 2002. Her autobiographical narrative reconstructs the mental map of migration undertaken both from the point of view of family relationships through drawings and a letter to the mother, who is in Turin. In this life story, the use of individual and collective memory are essential for carrying out the negotiation process of gender identity, and also serves to verify the identity changes that the mother has transmitted or silenced - from Europe - to her daughter.The separation and silence between mother and daughter creates discontinuities, broken mirrors of a gender identity that has to reproduce through memory, and with a new starting point, a distant migration and an indecipherable map from which is possible to know the new generations.

Keywords: gendered transnational identity, migration experience, memory, intersubjectivity, gender relationships, mental map, Europe. 